\title{
Protein quantity, not protein quality, accelerates whole-body leucine kinetics and the acute-phase response during acute infection in marasmic Malawian children
}

\author{
M. J. Manary ${ }^{1,2}$, K. E. Yarasheski ${ }^{2}$, S. Smith ${ }^{2}$, E. T. Abrams ${ }^{3}$ and C. A. Hart ${ }^{4}$ \\ ${ }^{1}$ College of Medicine, University of Malawi, Private Bag 360, Blantyre 3, Malawi \\ ${ }^{2}$ Departments of Pediatrics and Internal Medicine, Washington University School of Medicine, St Louis, MO 63110, USA \\ ${ }^{3}$ Department of Anthropology, University of Michigan, Ann Arbor, MI 48109, USA \\ ${ }^{4}$ Department of Medical Microbiology, University of Liverpool, Liverpool L69 3GA, UK
}

(Received 3 March 2004 - Revised 8 June 2004 - Accepted 21 June 2004)

\begin{abstract}
The present study compared leucine kinetics and acute-phase-protein concentrations in three groups of marasmic, acutely infected Malawian children fed one of three isoenergetic diets. These were: an enhanced-protein-quality diet (egg-white+tryptophan, providing $1 \cdot 2 \mathrm{~g}$ protein/kg per d; $n$ 14); an increased-protein-content diet (egg-white+tryptophan, providing $1.8 \mathrm{~g}$ protein $/ \mathrm{kg}$ per d; $n$ 14); a standard-protein diet $(1.2 \mathrm{~g}$ milk protein $/ \mathrm{kg}$ per d; $n 25)$. The hypotheses tested were that children receiving a diet with more protein would have greater rates of non-oxidative leucine disposal and that children receiving an isonitrogenous diet with a higher protein quality would have lower rates of leucine oxidation. The children were studied after $24 \mathrm{~h}$ of therapy using standard $\left[{ }^{13} \mathrm{C}\right]$ leucine stable-isotope tracer techniques. The children receiving the higher-protein-content diet had greater leucine kinetic rates than those receiving the standard-protein-content diet; non-oxidative leucine disposal was 170 (SD 52) v. 122 (SD 30) $\mu \mathrm{mol}$ leucine/kg per h $(P<0 \cdot 01$ ). Leucine oxidation was less in the children receiving the enhanced-protein-quality diet than in those receiving the standard-protein-quality diet; 34 (SD 12 ) $v .45$ (SD 13 ) $\mu \mathrm{mol}$ leucine/kg per $\mathrm{h}(P<0 \cdot 05)$. The children receiving the high-protein-content diet increased their serum concentration for five of six acute-phase proteins $24 \mathrm{~h}$ after starting therapy, while those receiving the standard-protein-content diet did not. These data suggest that there was greater whole-body protein synthesis, and a more vigorous acute-phase response associated with the higher-protein-content diet. The clinical benefits associated with a higher protein intake in marasmic, acutely infected children need further study.
\end{abstract}

Malnutrition: Therapy: Protein: Acute-phase response

Severe malnutrition and acute systemic infection are important determinants of whole-body protein kinetics. When dietary amino acid intake is reduced, such as occurs in malnutrition, there is decreased protein turnover (Jackson et al. 1983; Garlick et al. 1991). Proteolysis is reduced in malnutrition as well, which conserves the limited quantities of amino acids (Soares et al. 1994). Standard dietary recommendations for the initial treatment of children with severe malnutrition prescribe a very low total protein intake, $0 \cdot 9-1.2 \mathrm{~g} / \mathrm{kg}$ per d (World Health Organization, 1999), which may also contribute to the reduced rates of protein turnover. Acute infection, however, increases protein turnover (Long et al. 1977), probably by activating the acute-phase response, the accelerated synthesis of a group of proteins useful to the host in successfully responding to the infection (Szalai et al. 1995; Gabay \& Kushner, 1999).

Acute infection and malnutrition are often coincident and synergistic in children (Scrimshaw \& SanGiovanni, 1997).
In marasmic children with acute systemic infection receiving standard nutritional therapy, whole-body protein kinetics does not accelerate, and the acute-phase response is blunted (Manary et al. 2004). This blunted acute-phase response may well contribute to the compromised immune response typical of severe malnutrition. We tested two potential therapeutic strategies for overcoming this blunted acute-phase response in marasmus and acute infection. The first strategy was to provide dietary protein of higher quality, but in a standard amount. Higher dietary protein quality meant that the amino acid composition of the dietary protein was more similar to that of acute-phase proteins than was the standard milk protein. The second strategy was to provide a larger quantity of dietary protein.

The present study used a standard $\left[{ }^{13} \mathrm{C}\right]$ leucine stableisotope tracer dilution method (Matthews et al. 1980) to measure whole-body leucine kinetics in marasmic Malawian children with acute infection receiving either a diet with a standard total protein content, but a higher protein

\footnotetext{
Abbreviation: Ra, rate of appearance.

* Corresponding author: Dr Mark J. Manary, fax +1 314454 4345, email manary@kids.wustl.edu
} 
quality, a diet with a higher total protein content or the standard milk-protein diet. Specifically, the hypotheses tested were that children receiving an isonitrogenous diet with a higher protein quality would have a lower rate of leucine oxidation, but no more non-oxidative disposal of leucine, than those receiving standard therapy, while children receiving a diet with more protein would have a greater rate of non-oxidative leucine disposal.

\section{Methods}

\section{Subjects}

Children aged 12-60 months with marasmus admitted to Queen Elizabeth Central Hospital in Blantyre, Malawi from August 2000 to July 2002 were eligible. Marasmus was defined as having weight-for-age $<60 \%$ of the international standard (set by the Wellcome Trust Working Party; Anonymous, 1970) and evidence of wasting, manifest by weight-for-height $<80 \%$ of the international standard. After mothers gave their informed consent for their child's participation, each child was admitted to a special metabolic ward, which provided more intensive nursing care, better parenteral antibiotics, more frequent feedings and more careful clinical monitoring than the hospital ward. The initial evaluation of these children included blood culture, urine culture obtained by sterile catheter, chest X-ray, thick blood smear for malaria parasites and an ELISA for HIV (Vironostika HIV; Organon Teknika, Durham, NC, USA). Every child received parenteral ceftriaxone for the first $48 \mathrm{~h}$ after admission. Acute infection was defined as sepsis, malaria or pneumonia. Sepsis was defined as clinical signs of sepsis with a positive blood or urine culture, malaria was defined as clinical signs of falciparum malaria with a positive smear for malaria parasites, and pneumonia was defined as cough and tachypnea with a focal infiltrate on chest X-ray. The infections were believed to be acute because, according to the mothers' reports, each child's clinical condition had worsened within the day before admission. Children were said to recover if the symptoms of their acute infection resolved, their clinical status improved during their hospitalisation and they began to gain weight. The study was approved by the Human Studies Committee of Washington University in St Louis, MO and the College of Medicine Research Committee of the University of Malawi.

\section{Diets}

The standard diet provided $350 \mathrm{~kJ}(85 \mathrm{kcal}) / \mathrm{kg}$ per $\mathrm{d}$ and $1.2 \mathrm{~g}$ milk protein $/ \mathrm{kg}$ per $\mathrm{d}$. The diet with improved amino acid quality provided the same amount of energy and protein, but used egg-white with an added $1.5 \%$ tryptophan as a protein source. The high-protein diet provided $350 \mathrm{~kJ} / \mathrm{kg}$ per $\mathrm{d}$ and $1.8 \mathrm{~g}$ protein $/ \mathrm{kg}$ per $\mathrm{d}$; egg-white with $1.5 \%$ tryptophan was used as the dietary protein source. On the basis of the amino acid composition of a typical mixture of acute-phase proteins the fraction of each essential amino acid provided by the diet is shown in Table 1 (Reeds et al. 1994). Note that in the case of the standard milk diet, tryptophan is the limiting amino acid and the diet provides a complete complement of amino acids sufficient to synthesise $71 \%$ of a typical acute-phase response. For the egg-white + tryptophan diet providing a standard amount of protein, histidine is the limiting amino acid and the diet provides a complete complement of amino acids sufficient to synthesise $82 \%$ of a typical acute-phase response. The high-protein egg-white+tryptophan diet provides at least $120 \%$ of every essential amino acid needed for a typical acute-phase response. All children received a mineral-multivitamin supplement added to the feeding. Children were prospectively assigned to receive one of these diets by systematic allocation. Feedings were administered in equal amounts per $\mathrm{kg}$ body weight every $2 \mathrm{~h}$, and children unable to take feedings by mouth were fed through a nasogastric tube.

\section{Metabolic study}

The protocol and calculations for the metabolic study have been previously described and validated from a subset of the children included in the present report (Manary et al. 2002, 2003, 2004). Briefly, at $19 \mathrm{~h}$ after admission each child's $\mathrm{CO}_{2}$ appearance rate was determined with a primed $(2.5 \mu \mathrm{mol} / \mathrm{kg})$, constant $(5 \mu \mathrm{mol} / \mathrm{kg}$ per h) $70 \mathrm{~min}$ infusion of $\left[{ }^{13} \mathrm{C}\right]$ sodium bicarbonate $\left(99 \%{ }^{13} \mathrm{C}\right.$; Cambridge Isotopes, Andover, MA, USA). Before starting the $\left[{ }^{13} \mathrm{C}\right]$ sodium bicarbonate infusion breath samples were collected using a silicone rubber face mask connected to a non-diffusing gas collection bag (Hans Rudolph, Kansas City, MO, USA) to determine the baseline ${ }^{13} \mathrm{CO}_{2}$ isotope abundance. Breath samples were collected 60,65 and $70 \mathrm{~min}$ after the initiation of the $\left[{ }^{13} \mathrm{C}\right]$ sodium bicarbonate infusion for the measurement of the $\mathrm{CO}_{2}$ appearance rate. Immediately following the collection of these breath samples, a primed constant intravenous infusion of $\left[1-{ }^{13} \mathrm{C}\right]$ leucine $\left(99 \%{ }^{13} \mathrm{C}\right.$; Cambridge Isotopes, Andover, MA, USA) was begun. Each child received $\left[1-{ }^{13} \mathrm{C}\right]$ leucine (prime $15 \cdot 3 \mu \mathrm{mol} / \mathrm{kg}$, infusion $4 \mu \mathrm{mol} / \mathrm{kg}$ per $\mathrm{h}$ ) for $5 \mathrm{~h}$. During the $5 \mathrm{~h}$ infusion children received feedings in small portions every $30 \mathrm{~min}$. The amount of each feed was such that it provided the same rate of dietary energy intake $(350 \mathrm{~kJ} / \mathrm{kg}$ per d) as the $2 \mathrm{~h}$ feedings. This was done so that the metabolic measurements would reflect protein kinetics in the fed state rather than the postabsorptive state. At 4.5 and $5 \mathrm{~h}$ after the start of the leucine infusion, which corresponded to $24 \mathrm{~h}$ after admission and the initiation of feedings, a $1 \mathrm{ml}$ blood sample was drawn to measure plasma $\left[{ }^{13} \mathrm{C}\right] \alpha$-ketoisocaproic acid enrichment. Three breath samples were collected $4.5,4.75$ and $5 \mathrm{~h}$ after the start of the leucine infusion for the measurement of ${ }^{13} \mathrm{CO}_{2}$ isotope abundance, representative of leucine oxidation.

Sera for the measurement of the concentrations of six acute-phase proteins, C-reactive protein, properdin factor B, C3, haptoglobin, $\alpha_{1}$-anti-trypsin, and $\alpha_{1}$-acid glycoprotein were drawn on admission, $24 \mathrm{~h}$ after admission and $48 \mathrm{~h}$ after admission.

\section{Sample analyses}

In $10 \mathrm{ml}$ samples of breath, ${ }^{13} \mathrm{CO}_{2}:{ }^{12} \mathrm{CO}_{2}$ abundance was measured using an automated gas isotope ratio mass spectrometer (Finnigan MAT Delta+ XL; Bremen, Germany; Manary et al. 2003). 
Table 1. Essential amino acids provided for the typical acute-phase response in the milk and egg-white+tryptophan diets

\begin{tabular}{|c|c|c|c|c|}
\hline Amino acid & $\begin{array}{l}\text { Milk diet providing } \\
1.2 \mathrm{~g} \text { protein } / \mathrm{kg} \\
\text { per } \mathrm{d}\end{array}$ & $\begin{array}{l}\text { Egg-white+tryptophan } \\
\text { diet providing } 1.2 \mathrm{~g} \\
\text { protein } / \mathrm{kg} \text { per } \mathrm{d}\end{array}$ & $\begin{array}{l}\text { Egg-white+tryptophan } \\
\text { diet providing } 1.8 \mathrm{~g} \\
\text { protein } / \mathrm{kg} \text { per } \mathrm{d}\end{array}$ & $\begin{array}{c}\text { Estimated amino acid } \\
\text { requirements for a typical } \\
\text { acute-phase response }(\mathrm{mg} / \mathrm{kg})\end{array}$ \\
\hline Threonine (\%) & 84 & 84 & 126 & 65 \\
\hline Isoleucine (\%) & 135 & 126 & 189 & 54 \\
\hline Leucine (\%) & 132 & 114 & 171 & 89 \\
\hline Lysine (\%) & 106 & 91 & 136 & 90 \\
\hline Methionine (\%) & 131 & 180 & 270 & 23 \\
\hline Cysteine (\%) & 80 & 223 & 334 & 14 \\
\hline Phenylalanine (\%) & 74 & 89 & 134 & 79 \\
\hline Tyrosine (\%) & 106 & 85 & 128 & 55 \\
\hline Valine (\%) & 120 & 115 & 172 & 67 \\
\hline Arginine (\%) & 81 & 121 & 181 & 54 \\
\hline Histidine (\%) & 99 & 82 & 123 & 33 \\
\hline
\end{tabular}

$\%$, The fraction of amino acid provided in the diet to meet the estimated amino acid requirement for a typical acute-phase response (Reeds et al. 1994); the amount is listed in the last column.

Plasma $\alpha$-ketoisocaproic acid, the intracellular deamination product of leucine, was used to estimate intracellular $\left[{ }^{13} \mathrm{C}\right]$ leucine enrichment. Serum samples were analysed by GC electron impact-quadrupole MS (Agilent Technologies 6890N capillary GC system and 5973 Network Mass Selection Detector; Foster City, CA, USA) after the $\alpha$-ketoisocaproic acid was converted to its quinoxalinol trimethylsilyl derivative (Manary et al. 1997).

The concentrations of acute-phase proteins were measured by rate nephelometry (Beckmann Image Nephelometry System; Beckmann, High Wycombe, UK).

\section{Calculations and statistics}

The rates of appearance ( $\mathrm{Ra}$ ) of leucine and $\mathrm{CO}_{2}$ were calculated from the following equation, derived from a simple mass balance (Matthews et al. 1980):

$$
\mathrm{Ra}=((\mathrm{Ei} / \mathrm{Ep})-1) \times \mathrm{I},
$$

where $\mathrm{Ei}$ is the isotopic enrichment of the tracer infused $(99 \%), \mathrm{Ep}$ is the isotopic enrichment of the tracer in serum or breath, and $\mathrm{I}$ is the infusion rate of the tracer.

The rate of leucine oxidation was estimated from the following equation:

$$
\begin{aligned}
\mathrm{Ra}_{\text {Leuox }}= & \left(\mathrm{Ra}_{\mathrm{CO}_{2}}\right) \times\left({ }^{13} \mathrm{CO}_{2} \text { enrichment in breath }\right) \\
& \times(\mathrm{Ei} / \mathrm{Ep}-1) / 81,
\end{aligned}
$$

where $\mathrm{Ra}_{\mathrm{CO} 2}$ is the $\mathrm{Ra}$ of $\mathrm{CO}_{2}$ in breath, $\mathrm{Ei}$ is the isotopic purity of the leucine infused (98-99\%), and Ep is the plasma $\left[{ }^{13} \mathrm{C}\right] \alpha$-ketoisocaproic acid enrichment averaged over $4.5-5 \mathrm{~h}$. The factor 0.81 accounts for the fraction of $\mathrm{CO}_{2}$ that is produced by leucine oxidation, but not released from the body bicarbonate pool into the breath as determined by Matthews et al. (1980).

Leucine derived from whole-body proteolysis was calculated by subtracting the rate of leucine intake provided in the diet and $\left[{ }^{13} \mathrm{C}\right]$ leucine tracer infusion from $\mathrm{Ra}_{\text {Leu }}$, and non-oxidative leucine disposal was calculated by subtracting the rate of leucine oxidation from $\mathrm{Ra}_{\text {Leu }}$. Leucine derived from whole-body proteolysis and non-oxidative leucine disposal are indices of whole-body proteolysis and protein synthesis respectively.

The estimated sample size was thirteen children in each group, assuming that protein kinetics would vary similarly as children with kwashiorkor (Manary et al. 1997) and that differences of $10 \%$ between groups would be detected with $95 \%$ specificity and $80 \%$ power. Data are expressed as mean values and standard deviations. Anthropometric $Z$ scores were calculated using Epi Info 2000 (WHO/Centers for Disease Control, Atlanta, GA, USA). The protein kinetic data and acute-phase protein concentrations were tested for normality using the Kolmogorov-Smirnov test. After determining that the data were normally distributed, ANOVA was used to compare leucine kinetics between the groups of children and Student's paired $t$ test was used to compare acute-phase proteins within the groups over time. Statistical differences of $P<0.05$ were considered to be significant. The children that received the standard milk-protein diet have had their protein kinetic data reported previously (Manary et al. 2004).

\section{Results}

Fifty-three children were studied, with similar demographic and nutritional characteristics (Table 2). All twenty-eight children receiving either the high- or low-protein egg-white+tryptophan diet recovered, while of the twenty-five children receiving the milk-protein diet, twenty-two recovered and three died.

The constant $\left[{ }^{13} \mathrm{C}\right]$ sodium bicarbonate infusion reached an isotopic steady-state in breath ${ }^{13} \mathrm{CO}_{2}$ after $55 \mathrm{~min}$ of infusion and the plasma $\left[{ }^{13} \mathrm{C}\right]$ leucine enrichment equilibrated within $4 \mathrm{~h}$ as previously documented in a subset of these children (Manary et al. 2002, 2003).

The rates of non-oxidative leucine disposal and leucine derived from whole-body proteolysis were similar in the children receiving $1.2 \mathrm{~g}$ protein/ $\mathrm{kg}$ per $\mathrm{d}$ as either milk protein or egg-white+tryptophan, but greater in the children receiving $1.8 \mathrm{~g}$ protein $/ \mathrm{kg}$ per $\mathrm{d}$ as egg-white+tryptophan (Fig. 1). The leucine oxidation rate was higher when the diet of lower protein quality (milk) was consumed than 
Table 2. Demographic, anthropometric and clinical characteristics of study children (Mean values and standard deviations)

\begin{tabular}{|c|c|c|c|c|c|c|}
\hline & \multicolumn{2}{|c|}{$\begin{array}{l}\text { Milk diet providing } \\
1.2 \mathrm{~g} \text { protein } / \mathrm{kg} \text { per } \mathrm{d}\end{array}$} & \multicolumn{2}{|c|}{$\begin{array}{l}\text { Egg-white+tryptophan } \\
\text { diet providing } 1.2 \mathrm{~g} \\
\text { protein } / \mathrm{kg} \mathrm{per} \mathrm{d}\end{array}$} & \multicolumn{2}{|c|}{$\begin{array}{l}\text { Egg-white+tryptophan } \\
\text { diet providing } 1.8 \mathrm{~g} \\
\text { protein } / \mathrm{kg} \text { per d }\end{array}$} \\
\hline & Mean & $\mathrm{SD}$ & Mean & $\mathrm{SD}$ & Mean & SD \\
\hline Males & \multirow{2}{*}{\multicolumn{2}{|c|}{$\begin{array}{c}8 \\
17\end{array}$}} & \multirow{2}{*}{\multicolumn{2}{|c|}{$\begin{array}{l}7 \\
7\end{array}$}} & \multicolumn{2}{|c|}{8} \\
\hline Females & & & & & \multicolumn{2}{|c|}{6} \\
\hline Age (months) & 31 & 12 & 35 & 19 & 38 & 20 \\
\hline Weight-for-age $Z$ score & $-4 \cdot 1$ & 0.6 & $-4 \cdot 3$ & 0.5 & $-4 \cdot 3$ & 0.5 \\
\hline Height-for-age $Z$ score & -3.4 & 1.0 & -3.5 & 1.2 & -3.6 & 1.2 \\
\hline Weight-for-height $Z$ score & -2.9 & 0.6 & $-3 \cdot 1$ & $0 . \overline{8}$ & -3.0 & $0 . \overline{9}$ \\
\hline Clinical infections* & & & & & & \\
\hline Pneumonia & \multicolumn{2}{|c|}{12} & \multicolumn{2}{|c|}{7} & \multicolumn{2}{|c|}{8} \\
\hline Sepsis & \multirow{2}{*}{\multicolumn{2}{|c|}{$\begin{array}{c}8 \\
10\end{array}$}} & \multirow{2}{*}{\multicolumn{2}{|c|}{$\begin{array}{l}5 \\
3\end{array}$}} & \multicolumn{2}{|c|}{5} \\
\hline Malaria & & & & & \multicolumn{2}{|c|}{3} \\
\hline
\end{tabular}

* For clinical infections the number of children listed with each infection is given; some children had more than one infection.

it was when the diet of higher protein quality (egg-white + tryptophan) was consumed (Fig. 1).

In the children receiving the higher-protein-content diet, five of the six acute-phase protein concentrations (C-reactive protein, $\mathrm{C} 3$, properdin factor $\mathrm{B}$, haptoglobin and $\alpha_{1}$-acid glycoprotein) increased from admission to $24 \mathrm{~h}$ (Table $3 ; P<0 \cdot 05$ ). For the children receiving either of the lower-protein-content diets there were no significant differences in the concentration of any of the acute-phase proteins when those on admission were compared with $24 \mathrm{~h}$ measurements.

\section{Discussion}

Marasmic, acutely infected children who received the highprotein diet had greater rates of non-oxidative leucine disposal, suggesting that there was greater whole-body protein synthesis, and they exhibited a more vigorous acute-phase response as measured by serum acute-phase protein concentrations. The marasmic, acutely infected children who received the isonitrogenous diet of presumed higher protein quality oxidised leucine at a slower rate, which supports the notion that they were wasting less amino acids, however their total non-oxidative leucine disposal rate was similar to the children receiving the standard milk-protein diet.

The present study assumes that whole-body leucine kinetics mirrors whole-body protein kinetics, an assumption that has been made in a variety of human metabolic investigations. Leucine solutions for human infusion are safe, easy to prepare and stable (Bodamer et al. 1997). Clinical methods for their administration are robust. Kinetic calculations using leucine enrichments are relatively straightforward, because leucine is an essential amino acid with quantifiable intracellular fates; incorporation into proteins or deamination and subsequent oxidative decarboxylation (Matthews et al. 1980). As a tracer, $\left[{ }^{13} \mathrm{C}\right]$ leucine is inexpensive, and the laboratory methods for its analyses are standardised and simple. The fraction of leucine in a typical mixture of acute-phase proteins is $10.5 \%$, so leucine turnover is substantial during acute infection (Reeds et al. 1994). For these reasons we chose $\left[{ }^{13} \mathrm{C}\right]$ leucine as the tracer for the present study, and we believe that leucine kinetics mirrors whole-body protein kinetics in malnutrition and acute infection.

The estimation of the rate of $\mathrm{CO}_{2}$ production includes a factor to account for the $\mathrm{CO}_{2}$ which is produced, but not expired; this factor is based on experimental work done in adults and infants (Spear et al. 1995; Kien \& McClead, 1996). This factor has been measured in diverse populations, including critically ill children, and varies between 0.70 and 0.85 (Hoerr et al. 1989; Bresson et al. 1990; Tissot et al. 1993) although most reports have identified values between 0.77 and 0.82 (including those from critically ill infants). We did not measure the amount of $\mathrm{CO}_{2}$ produced that was then incorporated into other metabolic substrates in our population and this may have limited the accuracy of the present results. Another limitation of the study is that we measured simply the concentrations of acute-phase proteins, while others have measured their actual rate of synthesis (Jahoor et al. 1999). This would have required longer isotope infusions and much larger amounts of blood to be drawn from the subjects, which unfortunately was not possible in our context. No study subject had oedema at the time of their metabolic investigation, and thus these results may well not reflect protein metabolism in kwashiorkor and acute infection. Indeed whole-body protein kinetics in the two types of severe malnutrition, kwashiorkor and marasmus, has previously been shown to be different (Manary et al. 1998).

The estimations of amino acids needed for a typical acute phase were the only consideration in choosing the amino acid composition of the diet in the present study. In the time frame that was studied, the first $24 \mathrm{~h}$ of acute infection, it may be reasonable to consider amino acid requirements in this simple manner; synthesis of visceral proteins is suppressed and cell-mediated immune responses are just beginning to accelerate. However, whole-body protein synthesis is a dynamic and complex process which is incompletely understood; thus it is unlikely that amino acid requirements can be accurately estimated using such simplistic balance calculations. Several amino acids could potentially be limiting, and empirical data must be relied upon to determine how varying amino acid composition 


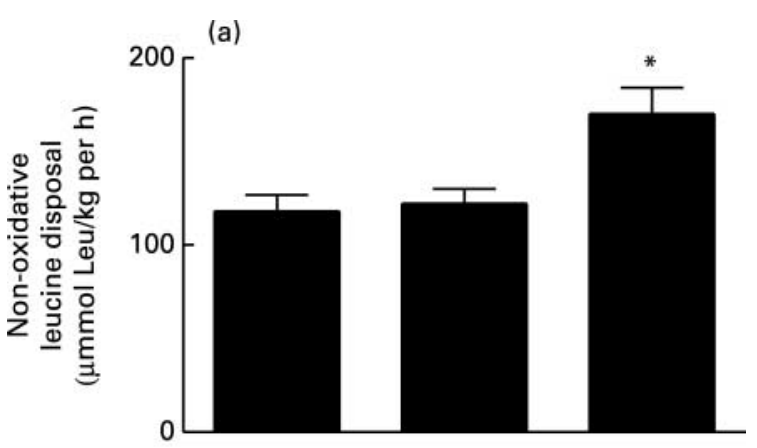

(b)

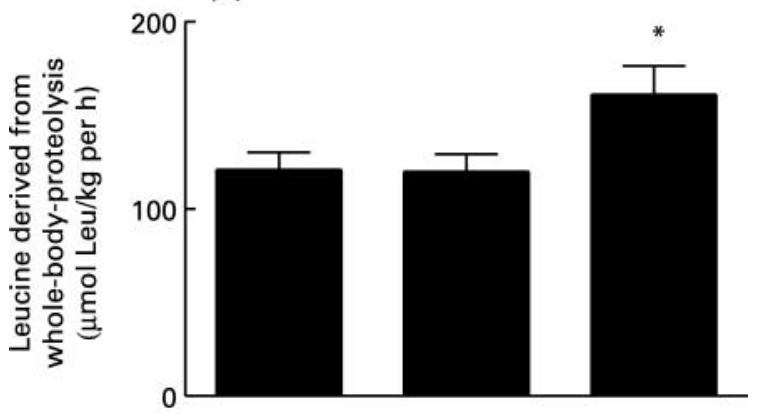

(c)

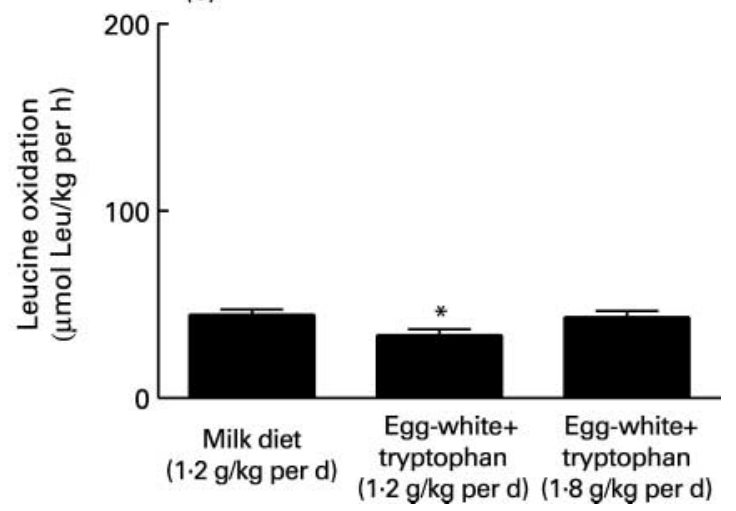

Fig. 1. Mean rates of non-oxidative leucine disposal (a), leucine derived from whole-body proteolysis (b) and leucine oxidation (c) in marasmic Malawian children with acute infection fed one of three isoenergetic diets: a standard diet with milk protein providing $1.2 \mathrm{~g}$ protein/kg per d; an improved-protein-quality diet with egg-white with added tryptophan providing $1.2 \mathrm{~g}$ protein/ $\mathrm{kg}$ per $\mathrm{d}$; a higher-protein-content diet with egg-white with added tryptophan providing $1.8 \mathrm{~g}$ protein $/ \mathrm{kg}$ per $\mathrm{d}$. Values are means, with standard errors of the mean represented by vertical bars. *Mean value was greater than those for the two other groups $(P<0.05$; ANOVA).

affects measurements of the immune response. Further studies on key amino acids hypothesised to be limiting protein synthesis during acute infection and malnutrition could be conducted by measuring non-oxidative leucine disposal in appropriate subjects assigned to receive diets that differ only in the amount of the single, key amino acid. The dietary threshold amount for a key amino acid could be determined by measuring the rate of non-oxidative leucine disposal and finding the point at which the dietary amount of the key amino acid was no longer associated with an increase in non-oxidative leucine disposal. Such studies may help define which amino acids are truly limiting in malnutrition and acute infection.
It is interesting that while the severity of malnutrition, measured by weight-for-height $Z$ score, was similar between the children receiving either the standard- or higher-protein-content diets, the children receiving more dietary protein had greater rates of leucine derived from whole-body proteolysis. How might increased dietary protein intake stimulate proteolysis? Ubiquitin-proteosomemediated protein degradation increases with physiological stress, such as acute infection, and is stimulated by glucocorticoids and pro-inflammatory cytokines, such as $\mathrm{TNF} \alpha$ and IL-1 (Hasselgren, 2000; Kee et al. 2003). Ubiquitinmediated proteolysis is not regulated by free amino concentrations, unlike lysosomal-mediated proteolysis (Kadowaki \& Kanazawa, 2003). In animal models, prolonged starvation suppresses ubiquitin activity (Martin et al. 2002). Acutely infected, marasmic children have been shown to have elevated levels of pro-inflammatory cytokines (Manary et al. 2004). Perhaps the higher dietary protein intake in these marasmic, infected children ameliorates the factors that are suppressing ubiquitin-mediated proteolysis in malnutrition, and allows proteolysis to be stimulated by the stress of acute infection.

The pattern of changes in acute-phase protein concentration observed suggests that giving more dietary protein during malnutrition and acute infection results in a more vigorous acute-phase response. The serum acute-phaseprotein concentrations among the marasmic children receiving $1.8 \mathrm{~g}$ protein $/ \mathrm{kg}$ per $\mathrm{d}$ were similar to those in well-nourished Malawian children with acute infection (Manary et al. 2004).

The recommendations for dietary protein intake during the initial phase of severe childhood malnutrition are $0.9-1.2 \mathrm{~g} / \mathrm{kg}$ per $\mathrm{d}$, and they are accompanied by the caveat that if larger amounts of energy and protein are given 'the child may develop a serious metabolic imbalance' (World Health Organization, 1999). Likewise, Waterlow (1992) recommends that $0.7 \mathrm{~g}$ protein $/ \mathrm{kg}$ per $\mathrm{d}$ be given initially, and states that larger quantities of any nutrient run the risk of 'overloading the system at both the physiological and biochemical levels'. These recommendations were developed by the thoughtful experts with extensive experience treating severe malnutrition in the developing world (Golden, 2002). Comparisons of clinical outcomes or metabolic parameters of diets providing different quantities of protein have not been published. Reports from starvation victims in 1945 fed veryhigh-protein diets, diets with protein:energy ratios $>30 \%$, indicate that upon refeeding many of these individuals died (Burger et al. 1945; Lipscomb, 1945). Collins et al. (1998) compared therapeutic feeding in malnourished adults with either a diet with a protein:energy ratio of $16.4 \%$ or a diet with a protein:energy ratio of $8.5 \%$ and found that the lower-protein-content diet was associated with reduced mortality. The standard recommendations for children call for a protein:energy ratio of $2-4 \%$, much lower than was used in these studies of adult malnutrition. While it seems that diets with very high protein intakes, $>5 \mathrm{~g}$ protein $/ \mathrm{kg}$ per $\mathrm{d}$, during the initial phase of treatment are dangerous, our data suggest that very low protein intakes may not provide enough amino acids for appropriate metabolic responses to stress. 
Table 3. Acute-phase protein concentrations

(Mean values and standard deviations)

\begin{tabular}{|c|c|c|c|c|c|c|}
\hline \multirow[b]{2}{*}{ Acute-phase protein } & \multicolumn{2}{|c|}{$\begin{array}{l}\text { Milk diet providing } 1.2 \mathrm{~g} \\
\text { protein } / \mathrm{kg} \text { per d }\end{array}$} & \multicolumn{2}{|c|}{$\begin{array}{l}\text { Egg-white+tryptophan } \\
\text { diet providing } 1.2 \mathrm{~g} \\
\text { protein } / \mathrm{kg} \text { per } \mathrm{d}\end{array}$} & \multicolumn{2}{|c|}{$\begin{array}{l}\text { Egg-white+tryptophan } \\
\text { diet providing } 1.8 \mathrm{~g} \\
\text { protein } / \mathrm{kg} \text { per } \mathrm{d}\end{array}$} \\
\hline & Mean & SD & Mean & SD & Mean & SD \\
\hline \multicolumn{7}{|c|}{ C-reactive protein (mg/l) } \\
\hline On admission & 72 & 50 & 78 & 68 & 75 & 59 \\
\hline After $24 \mathrm{~h}$ & 63 & 58 & 46 & 46 & $85^{\star}$ & 52 \\
\hline After $48 \mathrm{~h}$ & 39 & 37 & 25 & 27 & 35 & 33 \\
\hline \multicolumn{7}{|l|}{$\mathrm{C} 3(\mathrm{~g} / \mathrm{l})$} \\
\hline On admission & 0.71 & 0.42 & 0.86 & 0.39 & 0.78 & 0.40 \\
\hline After $24 \mathrm{~h}$ & 0.73 & 0.42 & 0.86 & 0.50 & $0.98^{*}$ & 0.69 \\
\hline After $48 \mathrm{~h}$ & 0.73 & 0.40 & 0.73 & 0.40 & $1.01^{*}$ & 0.63 \\
\hline \multicolumn{7}{|c|}{ Properdin factor B (g/l) } \\
\hline On admission & 0.42 & 0.17 & 0.51 & 0.18 & 0.46 & 0.18 \\
\hline After $24 \mathrm{~h}$ & 0.41 & 0.15 & 0.59 & $0 \cdot 19$ & $0 \cdot 71^{*}$ & 0.43 \\
\hline After $48 \mathrm{~h}$ & 0.39 & $0 \cdot 15$ & 0.51 & $0 \cdot 12$ & $0.68^{*}$ & 0.38 \\
\hline \multicolumn{7}{|l|}{ Haptoglobin (g/l) } \\
\hline On admission & 0.77 & 0.95 & 0.84 & 0.75 & 0.80 & 0.85 \\
\hline After $24 \mathrm{~h}$ & 0.89 & $1 \cdot 10$ & 0.83 & 0.73 & $0.87^{\star}$ & 1.03 \\
\hline After $48 \mathrm{~h}$ & 0.78 & 0.96 & 0.73 & 0.62 & 0.74 & 0.84 \\
\hline \multicolumn{7}{|c|}{$\alpha_{1}$-Acid glycoprotein ( $\left.\mathrm{g} / \mathrm{l}\right)$} \\
\hline On admission & $2 \cdot 6$ & 0.4 & $2 \cdot 9$ & 0.7 & $2 \cdot 7$ & 0.6 \\
\hline After $24 \mathrm{~h}$ & $2 \cdot 6$ & 0.4 & $3 \cdot 0$ & 0.8 & $3 \cdot 1^{*}$ & 1.0 \\
\hline After $48 \mathrm{~h}$ & 2.5 & 0.5 & $2 \cdot 7$ & 0.9 & 2.6 & 0.8 \\
\hline \multicolumn{7}{|l|}{$\alpha_{1}-$ Antitrypsin (g/l) } \\
\hline On admission & $2 \cdot 3$ & 0.6 & $2 \cdot 3$ & 0.7 & $2 \cdot 4$ & 0.6 \\
\hline After $24 \mathrm{~h}$ & $2 \cdot 3$ & 0.6 & $2 \cdot 0$ & 0.8 & 2.5 & 0.9 \\
\hline After $48 \mathrm{~h}$ & $2 \cdot 3$ & 0.6 & $1 \cdot 7$ & 0.8 & $2 \cdot 6$ & $1 \cdot 1$ \\
\hline
\end{tabular}

* The concentrations of C-reactive protein, $\mathrm{C} 3$, properdin factor $\mathrm{B}$, haptoglobin and $\alpha_{1}$-acid glycoprotein for the children receiving the high-protein diet increased from admission to $24 \mathrm{~h}$ or $48 \mathrm{~h}(P<0.05)$.

It is not known if the metabolic benefits associated with the higher-protein diet seen in the present study translate into genuine clinical benefits in the treatment of marasmic children, and a proper clinical trial of a higher-protein diet is needed to answer this question.

\section{Acknowledgements}

The present study was supported by National Institutes of Health (RO1HD38422), the Washington University Biomedical Mass Spectrometry Facility (NIH RR00954) and Clinical Nutrition Research Unit (NIH P30 DK56341).

\section{References}

Anonymous (1970) Classification of infantile malnutrition. Lancet ii, 302-303.

Bodamer OA, Leonard JV, Tasker RC, Hoffmann GF \& Halliday D (1997) Protein turnover in critically ill children. Eur J Pediatr 156, S59-S61.

Bresson JL, Mariotti A, Narcy P, Ricour C, Sachs C \& Rey J (1990) Recovery of $\left[{ }^{13} \mathrm{C}\right]$ bicarbonate as respiratory ${ }^{13} \mathrm{CO}_{2}$ in parenterally fed infants. Eur J Clin Nutr 44, 3-9.

Burger GCE, Sandstead HR \& Drummond J (1945) Starvation in Western Holland. Lancet ii, 282-283.

Collins S, Myatt M \& Golden B (1998) Dietary treatment of severe malnutrition in adults. Am J Clin Nutr 68, 193-199.

Gabay C \& Kushner I (1999) Acute-phase proteins and other systemic responses to inflammation. $N$ Engl $J$ Med 340, 448-454.

Garlick PJ, McNurlan MA \& Ballmer PE (1991) Influence of dietary protein intake on whole-body protein turnover in humans. Diabetes Care 14, 1189-1198.

Golden MHN (2002) The development of concepts of malnutrition. J Nutr 132, 2117S-2122S.

Hasselgren PO (2000) Catabolic response to stress and injury: implications for regulation. World J Surg 24, 1452-1459.

Hoerr RA, Yu YM, Wagner DA, Burke JF \& Young VR (1989) Recovery of ${ }^{13} \mathrm{C}$ in breath from $\mathrm{NaH}^{13} \mathrm{CO}_{3}$ infused by gut and vein: effect of feeding. Am J Physiol 257, E426-E438.

Jackson AA, Golden MH, Byfield R, Jahoor F, Royes J \& Soutter L (1983) Whole-body protein turnover and nitrogen balance in young children at intakes of protein and energy in the region of maintenance. Human Nutr Clin Nutr 37, 433-446.

Jahoor F, Gazzard B, Phillips G, Sharpstone D, Delrosario M, Fraser ME, Heird W, Smith R \& Jackson A (1999) The acute phase protein response to human immunodeficiency virus in human subjects. Am J Physiol 276, E1092-E1098.

Kadowaki M \& Kanazawa T (2003) Amino acids as regulators of proteolysis. J Nutr 133, 2052S-2056S.

Kee AJ, Combaret L, Tilignac T, Souweine B, Aurousseau E, Dalle M, Taillandier D \& Attaix D (2003) Ubiquitin-proteasome-dependent muscle proteolysis responds slowly to insulin release and refeeding in starved rats. J Physiol 546, $765-776$.

Kien CL \& McClead RE (1996) Estimation of $\mathrm{CO}_{2}$ production in enterally fed preterm infants using an isotope dilution stable tracer technique. J Parenter Enteral Nutr 20, 389-393.

Lipscomb FM (1945) Medical aspects of Belsen concentration camp. Lancet ii, 313-315. 
Long CL, Jeevanandam M, Kim BM \& Kinney JM (1977) Whole body protein synthesis and catabolism in septic man. Am J Clin Nutr 30, 1340-1344.

Manary MJ, Brewster DR, Broadhead RL, Graham SM, Hart CA, Crowley JR, Fjeld CR \& Yarasheski KE (1997) Whole-body protein kinetics in children with kwashiorkor and infection: a comparison of egg white and milk as dietary sources of protein. Am J Clin Nutr 66, 643-648.

Manary MJ, Broadhead RL \& Yarasheski K (1998) Whole-body protein kinetics in marasmus and kwashiorkor during acute infection. Am J Clin Nutr 67, 1205-1209.

Manary MJ, Yarasheski KE, Berger R, Abrams ET, Hart CA \& Broadhead RL (2004) Whole-body leucine kinetics and the acute phase response during acute infection in marasmic Malawian children. Pediatr Res 55, 940-956.

Manary MJ, Yarasheski KE, Berger R \& Broadhead RL (2003) $\mathrm{CO}_{2}$ production during acute infection in malnourished Malawian children. Eur J Clin Nutr 58, 116-120.

Manary MJ, Yarasheski KE \& Broadhead RL (2002) Urea production and leucine oxidation in malnourished children with and without infection. Metabolism 51, 1418-1422.

Martin SAM, Blaney S, Bowman AS \& Houlihan DF (2002) Ubiquitin-proteosome-dependent proteolysis in rainbow trout (Oncorhynchus mykiss): effect of food deprivation. Pflugers Arch 445, 257-266.

Matthews DE, Motil KJ, Rohrbaugh DK, Burke JF, Young VR \& Bier DM (1980) Measurement of leucine metabolism in man from a primed, continuous infusion of L- $\left[1-{ }^{13} \mathrm{C}\right]$ leucine. Am $J$ Physiol 238, E474-E479.

Reeds PR, Fjeld CR \& Jahoor F (1994) Do the differences between the amino acid compositions of acute-phase and muscle proteins have a bearing on nitrogen loss in traumatic stress? J Nutr 124, 906-910.

Scrimshaw NS \& SanGiovanni J (1997) Synergism of nutrition, infection and immunity: an overview. Am J Clin Nutr 66, 464S-477S.

Soares MJ, Piers LS, Shetty PS, Jackson AA \& Waterlow JC (1994) Whole body protein turnover in chronically undernourished individuals. Clin Sci 86, 441-446.

Spear ML, Darmaun D, Sager BK, Parsons WR \& Haymond MW (1995) Use of $\left[{ }^{13} \mathrm{C}\right]$ bicarbonate for measurement of $\mathrm{CO}_{2}$ production. Am J Physiol 268, E1123-E1127.

Szalai AJ, Briles DE \& Volanakis JE (1995) Human C-reactive protein is protective against fatal Streptococcus pneumoniae infection in transgenic mice. J Immunol 155, 2557-2563.

Tissot S, Delafosse B, Normand S, Bouffard Y, Annat G, Viale JP, Pachiaudi C, Riou JP \& Motin J (1993) Recovery of $\left[{ }^{13} \mathrm{C}\right]$ bicarbonate as respiratory ${ }^{13} \mathrm{CO}_{2}$ in mechanically ventilated patients. Am J Clin Nutr 57, 202-206.

Waterlow JC (1992) Protein-energy Malnutrition. London: Edward Arnold.

World Health Organization (1999) Management of Severe Malnutrition: a Manual for Physicians and Other Senior Health Workers. Geneva: WHO. 